\title{
FINANCIAL DEVELOPMENT AND ECONOMIC GROWTH:
}

LITERATURE SURVEY AND EMPIRICAL EVIDENCE FROM Sub-SaHaran African COUNTRIES ${ }^{1}$

\author{
Songul Kakilli Acaravci \\ Faculty of Economics and Administrative Sciences, Mustafa Kemal University, Turkey, \\ Ilhan Ozturk \\ Faculty of Economics and Administrative Sciences, Cag University, Turkey \\ Ali Acaravci \\ Faculty of Economics and Administrative Sciences, Mustafa Kemal University, Turkey
}

\begin{abstract}
In this paper we review the literature on the finance-growth nexus and investigate the causality between financial development and economic growth in sub-Saharan Africa for the period 19752005. Using panel co-integration and panel GMM estimation for causality, the results of the panel co-integration analysis provide evidence of no long-run relationship between financial development and economic growth. The empirical findings in the paper show a bi-directional causal relationship between the growth of real GDP per capita and the domestic credit provided by the banking sector for the panels of 24 sub-Saharan African countries. The findings imply that African countries can accelerate their economic growth by improving their financial systems and vice versa.
\end{abstract}

Abstract

Key Words: Financial development, growth, panel causality, sub-Saharan Africa

JEL C33, O11, 016, 055

1

\section{Introduction}

Academic research on the finance-growth nexus dates back at least to Schumpeter (1911) who emphasised the positive role of financial development on economic growth. The relationship between financial development and economic growth has been a subject of great interest and debate among economists for many years. The debate has traditionally revolved around two issues. The first relates to whether development in the financial system results in a faster economic growth, and the second relates to how financial development affects economic growth. A large body of literature has emerged, both at the theoretical and empirical level, attempting to answer the above questions. Although many empirical studies have investigated the relationship between financial depth, defined as the level of development of financial markets and economic growth, the results are ambiguous (see Pagano, 1993; and Levine, 1997, 2003 for a survey of the literature).

The theoretical relationships between financial development and economic growth have been analysed extensively in the literature and may be summarised under four hypotheses (Chuah \& Thai, 2004). First, the conventional view of the supply-leading hypothesis postulates that the direction of causality flows from financial development to economic growth. In a world without frictions caused by transaction, information and monitoring costs, no financial intermediaries are needed. If those costs are sufficiently high, no exchanges among economic agents will take place. The need to reduce those costs for exchanges to take place has led to the emergence of financial 
institutions and markets constituting the financial sector. A well-developed financial sector provides critical services to reduce those costs and thus to increase the efficiency of intermediation. It mobilises savings, identifies and funds good business projects, monitors the performance of managers, facilitates trading and the diversification of risks, and fosters exchange of goods and services. These services result in a more efficient allocation of resources, a more rapid accumulation of physical and human capital, and faster technological innovation, thus inducing faster long-term economic growth ${ }^{2}$.

Second, the demand-following hypothesis postulates that economic growth leads to financial development. The development of the real economy induces increased demand for financial services, which in turn, generate the introduction of new financial institutions and markets to satisfy that increased demand for financial services (Robinson, 1952; Patrick, 1966; and Demetriades \& Hussein, 1996).

Third, the bi-directional causality hypothesis is a combination of the supply-leading and demandfollowing hypotheses. It postulates that financial deepening and economic growth are mutually or bi-directionally causal (Greenwood \& Jovanovic, 1990; Saint-Paul, 1992; Berthelemy \& Varoudakis, 1996; Demetriades \& Hussein, 1996; Greenwood \& Smith, 1997; Blackburn \& Hung, 1998; and Harrison, Sussman \& Zeira, 1999). Financial deepening gradually induces economic growth and this, in turn, causes feedback and induces further financial deepening.

Fourth, the independent hypothesis postulates that financial deepening and economic growth are causally independent. Lucas (1988) argues that, at best, financial deepening plays a very minor role in economic growth; Stern (1989) ignores the role of financial development in the growth process.

The growing body of empirical research, using different statistical procedures and data sets, produces remarkably consistent results. First, countries with better-developed financial systems tend to grow faster - specifically, those with (i) large, privately owned banks that funnel credit to private enterprises and (ii) liquid stock exchanges. The levels of banking development and stock market liquidity each exert a positive influence on economic growth. Second, simultaneity bias does not seem to be the cause of this result. Third, better-functioning financial systems ease the external financing constraints that impede firm and industrial expansion. Thus, access to external capital is one channel through which financial development matters for growth because it allows financially constrained firms to expand (Levine, 2003).

The objective of this paper is to review the literature on the finance-growth nexus and investigate the causality between financial development and economic growth for 24 subSaharan African countries over the period 19752005. The paper contributes to the literature in exploring the growth-financial development nexus in the African context and provides some empirical evidence.

Our findings indicate that there is no long-run relationship between financial development and economic growth. Further, there is a bidirectional causal relationship between the growth of real Gross Domestic Product (GDP) per capita and the domestic credit provided by the banking sector for the panel data of 24 subSaharan African countries. We conclude that policies aimed at improving financial markets (economic growth) will have a significant effect on economic growth (financial development).

The rest of the paper is organised as follows: Section 2 presents a literature review. The model specification and data are presented in Section 3. The methodology and data are given in Section 4. The empirical results are discussed in Section 5. The paper concludes with a summary and policy implications.

\section{2}

\section{Empirical literature review}

In this section the empirical and theoretical background of the finance-growth nexus will be discussed in general and for the sub-Saharan Africa region separately.

\subsection{Empirical literature investigation on the finance-growth nexus}

An extensive number of empirical investigations has been conducted, aimed at testing the 
conflicting theoretical developments using different techniques. These empirical investigations can be classified into two major groups. The first group consists of those studies that used cross-country growth regression methods in which the average growth rate of per capita output over some period is regressed on some measure of financial development and a set of control variables (see King \& Levine, 1993a, b; Levine \& Zervos, 1998; De Gregorio \& Guidotti, 1995; Ndikumana, 2000, among others). The second group consists of those studies that used the time series data of individual countries to investigate the causal relationship between the two variables. The problems with the pure cross-country studies are well documented in the literature. In particular, the method fails to explicitly address the potential biases induced by the endogeneity of the explanatory variables and the existence of cross-country heterogeneity. These problems may lead to inconsistent and misleading estimates (see Quah, 1993; Casselli, Esquivel \& Lefort, 1996). In the light of these problems recent empirical studies have used dynamic panel data methods, such as the first differenced generalised methods of moments (GMM), as a way to control for the potential sources of biased coefficient estimates in cross-country regressions (see Levine, Loayza \& Beck, 2000; Benhabib \& Spiegel, 2000). The results of these studies provide evidence of a strong connection between the exogenous component of financial development and long-run economic growth. This is more or less consistent with the classical view on the relationship between growth and financial development.

The analysis of the causal relationship between banking sector development and economic growth was subjected to a more advanced econometric treatment in a paper by Levine et al (2000). They examined the role of financial development in a pooled cross-section setup using averaged data spanning the period 1960-1995. Using a GMM estimator, the authors show that the exogenous component of financial development is positive, significant and robust in the standard growth regressions. Moreover, Levine et al explain that unobserved country specific effects can be controlled for in a panel data setting and that panel data models offer a way to control for the potential endogeneity bias in all the explanatory variables by using "internal instruments" (i.e., lagged values of the explanatory variables). The dynamic panel estimations of Levine et al confirm that the weakly exogenous components of financial intermediary development exert a statistically significant and positive influence on economic growth. Moreover, the results pass both specification and sensitivity checks. The authors therefore conclude that "the data suggest a strong, positive link between financial intermediary development and economic growth" (Levine et al, 2000, p. 54).

Principal among existing econometric studies is the seminal paper by King and Levine (1993a), which is in the tradition of cross-country empirical studies of economic growth. King and Levine constructed four different financial development indicators ${ }^{3}$, and based on data for 77 different countries covering the period 19601989, they found that "higher levels of financial development are significantly and robustly correlated with faster current and future rates of economic growth, physical capital accumulation, and economic efficiency improvements" (King \& Levine, 1993a, p. 718-9). In addition, King and Levine conclude that the link between economic growth and financial development is not just a contemporaneous correlation. Instead, "finance seems importantly to lead economic growth" (King \& Levine, 1993a, p. 730).

The cross-country study started by Goldsmith (1969), which shows a graphically positive association between finance and growth, has subsequently been followed by several crosscountry studies. These added more countries and more variables for financial development and economic growth that were observed over longer periods. Studies with disaggregated data across industry and firm levels were also conducted. All these studies, while finding a positive association between finance and growth, do not conclude on whether finance causes growth. Levine and Zervos (1998), using data for 42 countries over the period 1976-1993, found a positive relationship between stock market development and growth, capital accumulation and productivity growth. 
Levine (1991) demonstrates that stock markets help individuals manage liquidity and productivity risk and, as a result, stock markets accelerate growth. According to Levine, in the absence of financial markets, firm-specific productivity shocks may discourage risk-averse investors from investing in firms. The more resources allocated to firms, the more rapid will be economic growth. Saint-Paul (1992) relates the relationship between the financial sector and economic growth by emphasising the complementary role between financial markets and technology. According to Saint-Paul, an economy that possesses highly developed financial markets, that allow the spreading of risk through financial diversification among the economic agents, will be able to achieve a higher level of development than an economy in which the financial markets are not well developed.

Khan and Senhadji (2000), in a cross-country and panel study, using data for 159 countries over the period 1960-1999, found that the effect of financial development on growth was positive, but the size of the effect varied with the different indicators of financial development, the estimation method, the data frequency and the functional form of the relationship. They did not deal formally with the causality issue. Financial development was measured by credit to the private sector, stock market capitalisation and bond market capitalisation as a share of GDP.

Christopoulos and Tsionas (2004) used panel co-integration analysis to examine whether a long-run relationship between financial development and economic growth existed for 10 developing countries over the period 1970-2000. Their findings support a unique co-integrating vector between growth, financial development, investment share and inflation, and uni-directional causality from financial depth to growth. However, this study limited its attention to only a few developing countries and employed only one measure of financial deepening.

Levine (1998), using a sample of 44 developed and less developed countries during the period 1975-1993, examined the links between banking development and long-run economic growth. The usual GMM estimation procedure was used to account for the simultaneity bias. The degree to which the legal codes emphasised the rights of the creditor and the efficiency of the legal system in enforcing laws and contracts were considered as instruments. The empirical evidence is supportive of a strong positive relationship between the exogenous component of banking development with output growth, physical accumulation and productivity growth.

Demirguc-Kunt and Maksimovic (1998) estimated a financial planning model and found that financial development facilitates the firm's growth. In this context an active stock market and a well-developed legal system are crucial for the further development of firms.

Beck, Levine and Loyaza (2000) investigated not only the relationship between financial development and economic growth but also the relationship between financial development and the sources of growth in terms of private saving rates, physical capital accumulation and total factor productivity. Once again, GMM and Instrumental Variable estimators were used to correct for possible simultaneity biases. The authors conclude that higher levels of financial development lead to higher rates of economic growth, and total factor productivity. For the remaining variables, they could not document any relationship with financial development.

The influence of the structure of the financial sector - bank-based (such as in Germany and Japan) and market-based (such as in the United Kingdom and the United States of America (USA)) financial systems - on economic growth has also been investigated. Several crosscountry studies show that the rates of growth of countries, industries or firms are not affected by the nature of the financial systems ${ }^{4}$.

Demirguc-Kunt and Levine (2001) found that as countries become richer the financial sector becomes more market-based. Levine (1997) concludes that those two systems are complementary in providing financial services to the economy as both have positive associations with economic growth. A number of studies suggest that it is more important to establish a credible environment to protect the rights of investors than being concerned with which system to develop 5 . The above cross-country studies found positive effects of financial 
development on growth for a "representative" country. From a policy viewpoint, those findings may not directly apply to specific countries (Luintel \& Khan, 1999). The time series approach addresses this issue by conducting the causality test for each country, thereby allowing individual countries to exhibit their own patterns of causality. Numerous studies have adopted this approach but the findings on the direction of causality are mixed, depending upon the country and the proxies used to measure financial development and economic growth.

Jung (1986) used more standard indicators of output and financial development and conducted causality tests using level vectorautoregressions (VAR) for 56 developed and developing countries. He found uni-directional causality from financial development to growth for the developing countries and the reverse causality from growth to finance in developed countries. However, the inference in a level VAR framework is problematic, because the variables have not been tested for stationarity and co-integration (see Sims, Stock and Watson, 1990).

Demetriades and Hussein (1996) and Thornton (1996) are among the few studies that have tested the financial-led hypothesis on several Asian countries. Using annual data from 1965 to 1992, Demetriades and Hussein found that among the Asian countries covered by the study, only in the case of Sri Lanka did the evidence support the financial-led growth hypothesis. For Pakistan, their result indicates that economic growth causes financial development. Further, Demetriades and Hussein's study suggests that bi-directional causal relationships are evident for India, South Korea and Thailand. Thornton (1996) provides some empirical evidence on the supply-leading hypothesis in several Asian countries. Using annual data as far back as the 1950s and up to 1990, Thornton found that the financial-led hypothesis was supported by the monetary data of Nepal, Malaysia, the Philippines and Thailand. The demand-following hypothesis was supported by Myanmar's and Korea's monetary data. However, a bi-directional relationship between the monetisation variable and economic growth was evident for Malaysia.
For a sample of six Asian countries, Luintel and Khan (1999) examined the long-run causality between financial development and economic growth employing a multivariate VAR framework. They found bi-directional causality between financial development and economic growth in all six countries, namely: India, Korea, Malaysia, the Philippines, Sri Lanka and Thailand. In another study on Asian economies, Al-Yousif (2002) found that the Philippines and Korea supported the financialled hypothesis, Sri Lanka and Pakistan supported the demand-following hypothesis, Malaysia and Singapore showed a two-way causal effect between financial development and growth, and the result for Thailand suggests finance was irrelevant for growth. Habibullah's (1999) study on seven developing Asian countries suggests that only the Philippines supports the financialled growth hypothesis. The demand-following growth hypothesis is supported by the data from Malaysia, Myanmar and Nepal. A bi-directional causality between growth and finance is evident for Indonesia, Sri Lanka and Thailand.

Habibullah and Eng (2006) examined the causal relationship between the financial development and economic growth of the developing Asian countries from a panel data perspective, they used the system GMM technique and conducted causality testing analysis. The panel data sets involved 13 developing Asian countries: Bangladesh, India, Indonesia, South Korea, Lao PDR, Malaysia, Myanmar, Nepal, Pakistan, the Philippines, Singapore, Sri Lanka and Thailand for the period 1990-1998. The result of their study is that financial development promotes growth, thus supporting the old Schumpeterian hypothesis and Patrick's "supply-leading" hypothesis.

Further evidence on the financial-led hypothesis is documented by Fase and Abma (2003). Using pooled data from Bangladesh, India, Malaysia, Pakistan, the Philippines, Singapore, South Korea, Sri Lanka and Thailand, they conclude that financial development matters for economic growth and that causality runs from the level of financial intermediation and sophistication to growth.

Al-Zubi, Al-Rjoub and Abu-Mhareb (2006) applied a model developed by Levine in 1997 
using panel data for 11 Arab countries during the period 1980-2001. The results show that all the financial indicators are insignificant and do not affect economic growth. The modified model shows that only the public credit to domestic credit indicator has a significant and positive effect on economic growth, indicating the dominance of the public sector in economic activities and that the financial sectors are still under-developed and need to expend more effort towards fulfilling their functions effectively in the Arab countries. Pinero et al (2005) tested the hypothesis of a positive impact of democratisation on growth, economic development and changes in wellbeing. They constructed an empirical model to explain the impact of political institutions (democracy), economic institutions, financial market efficiency, scientific achievements and "financial or FDI" geography on growth. The empirical work, based on a wide database including several indicators assessed by the authors, supports the hypothesis of the decisive role of democratic political and efficient economic institutions in stimulating economic growth for over 80 countries. The main results also highlight the importance of the effective allocation of financial resources.

The supply-leading hypothesis is also supported by more recent studies by Calderon and Liu (2003) on 109 developing and developed countries, and Christopoulos and Tsionas (2004) on 10 developing countries. Both studies conclude that the supply-leading hypothesis is the dominant force behind the relationship between finance and the sources of growth, in particular, financial depth contributes more to the causal relationship in developing countries.

Atje and Jovanovic (1993) examined the effect of stock markets on development and conclude that there is a positive effect on the level of development as well as on growth. They could not, however, establish a significant relationship between bank liabilities and growth.

Levine and Zervos (1996) used various measures of stock market development, and conclude that there is a significant relationship. When they included banking depth variables in their regressions, the variables turned out to be non-significant. They emphasise that their results are indicative of partial correlation only, and that more research is needed in the area.

Arestis and Demetriades (1997) used time series analysis and Johansen co-integration analysis for the USA and Germany. For Germany, they found an effect of banking development on growth. In the USA, there was insufficient evidence to claim a growth effect of financial development, and the data point to the direction that real GDP contributes to both the banking system and stock market development.

Apergis, Filippidis and Economidou (2007) examined whether a long-run relationship between financial development and economic growth exists employing panel integration and co-integration techniques for a dynamic heterogeneous panel of 15 Organisation for Economic Co-operation and Development (OECD) and 50 non-OECD countries over the period 1975-2000. Three different measures of financial deepening were used to capture the variety of different channels through which financial development can affect growth. Their findings support the existence of a single longrun equilibrium relationship between financial deepening, economic growth and a set of control variables. Further, the evidence points to a bi-directional causality between financial deepening and growth.

Chuah and Thai (2004) investigated the causal relationship between financial development and economic growth in the six countries of the Gulf Cooperation Council (GCC). Using Error Correction Model (ECM) and VAR models for causality testing, they found evidence of bidirectional causality in five countries and finance leading growth in the last one. The results are very much country-specific and dependent on the proxies chosen for financial development or economic growth. These results indicate that GCC countries should continue to promote financial development while pursuing the needed reforms to develop the real sector.

Some more recent studies focused on the finance-growth causality nexus in the Middle East. Darrat (1999) performed causality tests on three countries (Saudi Arabia, Turkey and the United Arab Emirates (UAE)). The study 
finds finance leads growth in Turkey, growth causes finance in the UAE, and bi-directionality in Saudi Arabia. He concludes that financial deepening causes economic growth, although the results are country-specific and vary across the proxies used to measure financial deepening or economic growth. Boulila and Trabelsi (2002) found that financial reforms in Tunisia changed the pattern of causality from growth to finance in the pre-reform period to bi-directional causality in the post-reform period. Using annual data from 1975-2005 for Turkey, Ozturk (2008) found that there was no long-run relationship between financial development and economic growth and the results show a one-way causality running from economic growth to financial development.

Several theoretical and empirical studies have suggested that the role of financial development in the economy may vary across countries because of differences in institutional and economic structures (see LaPorta et al, 1997; and Bell \& Rousseau, 2001, among others). On the one hand there are those who argue that, in a given economy, it is the sector with high economies of scale that benefits more from financial development (Kletzer \& Pardhan, 1987; Beck, 2002), implying that financial development is much more effective in promoting economic growth in more industrialised economies than in less industrialised or agricultural economies. On the other hand, there are those who contend that countries in the early stages of their development benefit more from financial development (see McKinnon, 1973; Fry, 1995). Moreover, it is argued that the effectiveness of financial intermediaries and markets in promoting economic growth depends on the institutions set up to implement financial transactions. For example, LaPorta et al (1997) found that the legal system plays a crucial role in determining financial development and growth relationships. They argue that secure property and contract rights are crucial to banks and financial institutions working properly, while weak contract enforcement creates incentives for default by debtors and decreases willingness to lend. In addition, they point out that corruption in the banking system or political interference may divert credit to unproductive or even wasteful activities, again implying that economies with developed institutions are likely to benefit more from financial development.

\subsection{Empirical literature survey on sub-Saharan Africa}

Odedokun's (1996) study determined and analysed the effects of financial intermediation on the growth of real GDP in Least Developed Countries (LDCs) by employing annual data for 71 countries over varying periods that generally span the 1960s and 1980s. His findings are as follows: (a) financial intermediation promotes economic growth in about 85 per cent of the countries; (b) compared with factors that have often been emphasised in the literature (viz. export expansion, capital formation ratio and labour force growth) as important growth promoters, financial intermediation is practically on par with export expansion and capital formation ratio, and superior to labour force growth, as a partner to promoting economic growth; (c) the growth-promoting effects of financial intermediation are more predominant in low-income than in high-income LDCs; and (d) the growth-promoting effects of financial intermediation are practically invariant across the various regions of the globe.

Akinboade (1998) examined the relationship between financial development and economic growth in Botswana. Two indicators were used to examine Granger causality between real per capita income and financial development. An error-correction method was adopted following the tests for unit roots and co-integration. The study suggests that per capita income in Botswana and the financial development indicators cause one another, supporting the view that economic growth causes and is caused by financial development in Botswana.

Agbetsiafa (2003) found that each of the financial development indicators and economic growth are integrated at the first order. The co-integration test results show that financial development and economic growth are linked in the long run in seven of the eight countries in the sample. Causality tests indicate a preponderance of uni-directional causality from finance to growth in six of the countries. 
Ghirmay (2004) examined the causal link between the level of financial development and economic growth in 13 sub-Saharan African countries. The results of the co-integration analysis provide evidence of the existence of a long-run relationship between financial development and economic growth in almost all (12 out of 13) of the countries. With respect to the direction of long-term causality, the results show that financial development plays a causal role on economic growth, again in eight of the countries. At the same time, evidence of bi-directional causal relationships is found in six countries. The findings imply that African countries can accelerate their economic growth by improving their financial systems.

Odhiambo (2005) investigated empirically the role of financial development on economic growth in Tanzania. The study used three proxies of financial development against real GDP per capita (a proxy for economic growth). Using the Johansen-Juselius co-integration method and a vector ECM, the empirical results of this study, taken together, reveal a bi-directional causality between financial development and economic growth in Tanzania - although a supply-leading response tends to predominate.

Atindehou, Gueyie and Amenounve (2005) used causality tests to empirically examine the relationship between finance and economic growth, in the context of West African country members of the Economic Community of West African States. In all but a few countries, the results indicate a weak causal relationship between finance and economic development on one side, and between economic development and finance on the other side. These results imply, ceteris paribus, that leaders of West African countries should focus their economic and monetary policies on the development of financial intermediation, which in turn will favour economic growth.

Adjasi and Biekpe (2006) studied the effect of stock market development on economic growth in 14 African countries in a dynamic panel data modelling setting. Results largely show a positive relationship between stock market development and economic growth. The results reveal that the positive influence of stock market development on economic growth is significant for countries classified as upper middle income economies. On the basis of market capitalisation groupings, stock market developments play a significant role in growth only for moderately capitalised markets. The general trend in results shows that low income African countries and less developed stock markets need to grow more and develop their markets to elicit economic gains from stock markets.

Odhiambo (2007) investigated empirically the direction of causality between financial development and economic growth in three sub-Saharan African countries - Kenya, South Africa and Tanzania. Using three proxies of financial development against real GDP per capita (a proxy for economic growth), the study finds that the direction of causality between financial development and economic growth is sensitive to the choice of measurement for financial development. In addition, the strength and clarity of the causality evidence varies from country to country and over time. On balance, a demand-following response is found to be stronger in Kenya and South Africa, whilst in Tanzania a supply-leading response is found to be dominant.

Quartey and Prah (2008) conducted a study to find out whether financial development in Ghana conformed to either the supplyleading, demand-following or Patrick's Stages of development hypotheses. Whereas there is some evidence in support of the demandfollowing hypothesis when the growth of broad money to GDP ratio is used as a measure of financial development, there is no significant evidence to support either the supply-leading or demand-following hypothesis when the growth in domestic credit to GDP ratio, private credit to GDP ratio, and private credit to domestic credit ratio are used as proxies for financial development.

Odhiambo (2008) attempted to examine the dynamic causal relationship between financial depth and economic growth in Kenya by including savings as an intermitting variable - thereby creating a simple tri-variate causality model. Using the co-integration and errorcorrection techniques, the empirical results of this study reveal that there is a distinct unidirectional causal flow from economic growth 
to financial development. The results also reveal that economic growth causes savings, while savings drive the development of the financial sector in Kenya. The study, therefore, warns that any argument that financial development unambiguously leads to economic growth should be treated with extreme caution.

Enisan and Olufisayo (2008) examined the long-run and causal relationships between stock market development and economic growth for seven countries in sub-Saharan Africa. Using the autoregressive distributed lag bounds test, the study finds that stock market development is cointegrated with economic growth in Egypt and South Africa. Moreover, this test suggests that stock market development has a significant positive long-run impact on economic growth. The Granger causality test based on a vector ECM further shows that stock market development causes economic growth in Egypt and South Africa. However, the Granger causality in the context of VAR shows evidence of a bi-directional relationship between stock market development and economic growth for Cote d'Ivoire, Kenya, Morocco and Zimbabwe. In Nigeria, there is weak evidence of growth-led finance using market size as the indicator of stock market development.

In summary, the picture that emerges from the different econometric studies is blurred. In cross-section studies there is a positive correlation between financial development and growth, but in the poorest countries the correlation is negative. In individual-country studies, different causal patterns between financial development and economic growth are characteristic. In some countries, finance seems to lead growth, while there is reverse causality or no clear causal link elsewhere. Moreover, conclusions are very sensitive to the type of estimator used and slight changes in nuisance parameters often change the results (Andersan and Tarp, 2003).

\section{3}

\section{Model specification and data}

In the finance-growth nexus literature there are interesting and controversial views about the appropriate measure of financial development.
Many researchers used the liquid liabilities of the financial system as financial depth (see Goldsmith, 1969; McKinnon, 1973; and King \& Levine, 1993a, 1993b). A higher financial depth implies a larger financial sector and, therefore, greater financial intermediary development. But Levine and Zervos (1998) argue that M3/GDP measures only financial depth and there is no theoretical relationship between this ratio and economic growth. They propose that bank credit is useful in measuring financial development. Therefore, the credit given to the private sector represents an accurate indicator of the functioning of financial development because it is a measure of the quantity and quality of investment (see De Gregorio \& Guidotti, 1995; Demetriades \& Hussein, 1996; Levine \& Zervos, 1998; Levine et al, 2000).

Ndikumana (2000) employed the following financial development indicators: credit to the private sector, total liquid liabilities of the financial system, credit provided by banks, and an index combining these three indicators. Ndikuma indicates that it is private investment that is most dependent on financial development in sub-Saharan Africa. In addition, Ghirmay (2004) also emphasises that most of the financial developments have occurred within the banking system in African countries.

To investigate the causality between financial development and economic development in subSaharan Africa, we employ panel co-integration and panel causality methods. Such a model may be specified as:

$G D P_{i t}=a_{i}+\beta_{i} F D_{i t}+\varepsilon_{i t}$

where $G D P_{i t}$ is the natural logarithm of real GDP per capita, PPP (constant 2000 international \$); $F D_{i t}$ is the measure of financial development, and $\varepsilon_{i t}$ is the error term. Following the literature, we use real GDP per capita as a measure for economic development (see King and Levine, 1993a, 1993b; Levine and Zervos, 1998; De Gregorio and Guidotti, 1995; Ndikumana, 2000, among others. See also Odedokun, 1996; Akinboade, 1998; and Odhiambo, 2005, 2007, 2008, among others for the sub-Saharan African countries) and three financial indicators measures, which are commonly adopted in the literature: i) Bank credit (BC) is defined as the 
domestic credit provided by the banking sector (percentage of GDP); ii) Private sector credit (PC) equals the domestic credit to the private sector (percentage of GDP), the indicator PC includes non-bank credit to the private sector; and iii) The liquid liabilities of the financial system (LL) are broad money (M3) (percentage of GDP). Liquid liability is defined as currency plus demand and the interest bearing liabilities of bank and non-bank financial intermediaries divided by the GDP. The last is the broadest measure of financial depth used, since it includes all types of financial institutions (central bank, deposit money banks and other financial institutions).

The annual time series data are taken from the World Development Indicators (WDI) online for the period 1975-2005 in the form of balanced panel data. The sample includes 24 sub-Saharan African countries: Benin, Burkina Faso, Burundi, the Central African Republic, Chad, Congo Republic, Cote d'Ivoire, Gabon, Gambia, Ghana, Kenya, Madagascar, Malawi, Mali, Niger, Nigeria, Rwanda, Senegal, the Seychelles, Sierra Leone, South Africa, Sudan, Swaziland and Togo. These countries are selected according to data availability from among 48 sub-Saharan African countries.

\section{4 \\ Methodology}

Examining the relationship between financial development and economic growth will be performed in two steps. First, we define the order of integration in series and explore the long-run relationships between the variables by using heterogeneous panel unit root tests and a heterogeneous co-integration test, respectively. Second, we test causality using the panel GMM estimator.

\subsection{Panel integration analysis}

Recent literature emphasises that panel unit root tests are more accurate than univariate unit root tests. For the sub-Saharan African countries, heterogeneity arises because of the differences in the economic conditions and the degree of development in each country.
Therefore, we employ two recently developed heterogeneous panel unit root tests to check whether the variables in our model are stationary or non-stationary. These tests are the Fisher Augmented Dickey-Fuller (Choi, 2001) and the Im, Pesaran and Shin (IPS, 2003) that take heterogeneity into account using individual effects and individual linear trends.

Choi (2001) considers the model:

$y_{i t}=d_{i t}+x_{i t}\left(i=1, \ldots, N ; t=1, \ldots, T_{i}\right)$

where $d_{i t}=\beta_{i 0}+\beta_{i 1}+\ldots+\beta_{i m i} t^{m i}, x_{i t}=\alpha_{i} x_{i(t-1)}+$ $u_{i t}$ and $u_{i t}$ is integrated of order zero. Choi allows each time series, $y_{i t}$, to have a different sample size and a different specification of nonstochastic and stochastic components depending on $i$. The null hypothesis is that all the individual series in the panel are non-stationary $\left(H_{0}: \alpha_{i}=1\right.$ for all $i)$, the alternative hypothesis is that some of the time series are stationary $\left(H_{0}:\left|\alpha_{i}\right|<1\right.$ for some $i$ 's). Choi proposed a Fisher-type test:

$Z=\frac{1}{\sqrt{N}} \sum_{1}^{N} \Phi^{-1}\left(p_{i}\right)$

Where $\Phi$ is the standard normal cumulative distribution function and $0 \leq p_{i} \leq 1, \Phi^{-1}\left(p_{i}\right)$ is a $N(0,1)$ random variable and $T_{i} \rightarrow \infty$ for all $i$, $Z \Rightarrow N(0,1)$.

Im et al (2003) using the IPS test also developed a unit root test for dynamic heterogeneous panels based on the mean of the individual unit root statistics. Im et al propose a standardised t-bar test based on the ADF statistics averaged across the groups. The stochastic process, $y_{i t}$, is generated by the first-order autoregressive process:

$y_{i t}=\left(1-\phi_{i}\right) \mu_{i}+\phi_{i} y_{i, t-1}+\varepsilon_{i t}$

$i=1, \ldots N ; t=1, \ldots T$

where the initial values, $y_{i 0}$, are given. In the testing, the null hypothesis of the unit roots, $\phi_{i}=1$ for all $i$. Equation (3) can be expressed:

$\Delta y_{i t}=\alpha_{i}+\beta_{i} y_{i, t-1}+\varepsilon_{i t}$,

The null hypothesis is that each individual series in the panel has a unit root; the alternative hypothesis allows for $\alpha_{i}$ to differ across the groups:

$H_{0}: \beta_{i}=0$ for all $i$ 
$H_{1}, \beta_{i}<0, \quad i=1,2, \ldots, N_{1}, \beta_{i}=0$,

$i=N_{1}+1, N_{1}+2, \ldots, N$

The modified standardised $t_{I P S}$ statistic below is distributed as $N(0,1)$ when $T \rightarrow \infty$ followed by $N \rightarrow \infty$ sequentially:

$t_{I P S}=\frac{\left.\sqrt{N}\left(\bar{t}-\frac{1}{N} \sum_{i=1}^{N} E\left[t_{i T} \mid \beta_{i}=0\right]\right)\right)}{\sqrt{\left.\frac{1}{N} \sum_{i=1}^{N} \operatorname{var}\left[t_{i T} \mid \beta_{i}=0\right]\right)}}$

\subsection{Panel co-integration analysis}

Pedroni $(1997,1999)$ developed a residual-based panel co-integration method that also allows a lot of heterogeneity through individual effects, slope coefficients and individual linear trends across countries. Pedroni (2004) considered the following type of regression:

$y_{i t}=\alpha_{i}+\delta_{i} t+\beta_{i} X_{i t}+\varepsilon_{i t}$

for a time series panel of observables $y_{i t}$ and $X_{i t}$ for members $i=1, \ldots, N$ over time periods $t=1, \ldots$ $T$. The variables $y_{i t}$ and $X_{i t}$ are assumed to be integrated of order one, denoted I(1). The parameters $\alpha_{i}$ and $\delta_{i}$ allow for the possibility of individual effects and individual linear trends, respectively. The slope coefficient $\beta_{i}$ is also permitted to vary from individual to individual, so, in general, the co-integrating vectors may be heteregenous across the members of the panel.

Pedroni (1999) derived the asymptotic distributions and explored the small sample performances of seven different statistics to test panel data co-integration. His tests can be classified into two categories: The first four test statistics are based on pooling along what is often referred to as the "within" dimension (called "panel" hereafter). These tests are the panel-v, panel-rho, panelnon-parametric (pp) and panel-parametric (adf) statistics. The last three test statistics are based on the "between" dimension (called "group" hereafter). These tests are group-rho, group-pp and group-adf statistics. The null hypothesis is $H_{0}$ $: \hat{a}_{i}=1$ (i.e., no co-integration) for all tests and the alternative hypotheses are $H_{1}: \hat{a}_{i}=\hat{a}<1=$ $H_{1}: \hat{a}<1$ and for the first four tests and the last three tests, respectively. The small sample size properties for the seven statistics have also been re-investigated by Pedroni (2004) via Monte
Carlo simulations. In terms of power, for smaller samples $(\mathrm{N}=20)$ the group-rho statistic is the most powerful, followed by the panel-rho and panel-adf statistics. The calculated test statistics must be smaller than the tabulated critical value to accept the null hypothesis of absence of co-integration.

\subsection{Panel causality analysis}

The panel co-integration method tests for the existence or absence of long-run relationships between financial development and economic growth. The test does not indicate the direction of causality. But one can estimate causality using the panel GMM estimator as developed by Holtz-Eakin, Newey and Rosen (1988, 1989), and Arellano and Bond (1991). To test for panel causality, the most widely used method in the literature is that proposed by Holtz-Eakin, Newey and Rosen, (1988, 1989). Their timestationary VAR model is of the form:

$$
\begin{aligned}
G D P_{i t}= & \alpha_{0}+\sum_{j=1}^{m} \alpha_{j} G D P_{i t-j}+\sum_{j=1}^{m} \beta_{j} F D_{i t-j} \\
& +\mu_{i}+\varepsilon_{i t} \\
F D_{i t}= & \delta_{0}+\sum_{j=1}^{m} \delta_{j} G D P_{i t-j}+\sum_{j=1}^{m} \gamma_{j} F D_{i t-j} \\
& +\eta_{i}+v_{i t}
\end{aligned}
$$

where $\varepsilon_{i t}$ and $v_{i t}$ are error terms, and $\mu_{i}$ and $\eta_{i}$ are individual fixed effects. The test of whether financial development (FD) causes GDP is simply a test of the joint hypothesis that is $\beta_{1}=\beta_{2}=\ldots=\beta_{\mathrm{m}}=0$. Nickell (1981) shows that including the fixed effects and the lagged dependent variables correlated with the error terms leads to biased estimation. Anderson and Hsiao (1981) recommend using the first difference operator to eliminate the individual fixed effects. $\Delta$ indicates the first difference operator, the resulting model becomes:

$$
\begin{aligned}
\Delta G D P_{i t}= & \sum_{j=1}^{m} \alpha_{j} \Delta G D P_{i t-j}+\sum_{j=1}^{m} \beta_{j} \Delta F D_{i t-j} \\
& +\Delta u_{i t} \\
\Delta F D_{i t}= & \sum_{j=1}^{m} \delta_{j} \Delta G D P_{i t-j}+\sum_{j=1}^{m} \gamma_{j} \Delta F D_{i t-j} \\
& +\Delta v_{i t}
\end{aligned}
$$

If the errors move by an average of the order $k$ in the model at all levels, they will move by an average of the order $k+1$ at the first difference and, therefore, Anderson and Hsiao (1981) 
suggest using some instrumental variables to get a consistent estimation of the parameters. The panel GMM estimator combines the level equations ( 9 and 10 ) and the differenced equations (11 and 12) in a system. This estimator uses the lagged levels as an instrument in the difference regressions and the most recent difference as an instrument in the level regressions. The panel GMM estimator is based on the assumption of no second-order autocorrelation in the firstdifferenced residuals.

\section{5 \\ Empirical results}

\subsection{Panel integration and co-integration results}

Table 1 presents the results derived from the two heterogeneous panel unit root tests for the order of panel integration. The maximum lags are based on Schwarz information criterion (SIC) for these tests that assume the null hypothesis of each individual series is nonstationary. Both the panel unit root tests have the same results: The null hypothesis of the unit roots cannot be rejected for GDP and PC series at all the levels but it is strongly rejected at the 1 per cent significance level at their first difference. The BC and LL series are stationary at the 5 per cent and 1 per cent significance levels, respectively. So we conclude that the real GDP per capita and the domestic credit to private sector (percentage of GDP) series are $\mathrm{I}(1)$, while the domestic credit provided by the banking sector (percentage of GDP) and M3 broad money (percentage of GDP) series are $\mathrm{I}(0)$.

Table 1

Panel unit root tests

\begin{tabular}{|l|c|c|c|c|}
\hline \multicolumn{1}{|c|}{ Variables } & \multicolumn{2}{|c|}{ Fisher ADF } & \multicolumn{2}{c|}{ IPS } \\
\hline & Levels & Differences & Levels & Differences \\
\hline GDP & $0.3470(6)$ & $-14.4122(5)^{* * *}$ & $-0.0277(6)$ & $-16.7907(5)^{* * *}$ \\
\hline BC & $-1.7783(6)^{* *}$ & & $-2.1601(6)^{* *}$ & \\
\hline PC & $-1.2807(5)$ & $-14.6338(2)^{* * *}$ & $-1.2691(5)$ & $-17.3955(2)^{* * *}$ \\
\hline LL & $-2.5656(3)^{* * *}$ & & $-2.8317(3)^{* * *}$ & \\
\hline Note: Maximum lags in ( ).*** and ** indicate significance at the $1 \%$ and 5\% levels, respectively. \\
\hline
\end{tabular}

We can apply the Pedroni panel co-integration test for only the real GDP per capita and the domestic credit to the private sector (percentage of GDP) in order to determine if there is a long-run relationship between the two variables. Table 2 presents the heterogeneous panel cointegration test results. All tests accept the null hypothesis of no co-integration against the alternative of co-integration. This means that there is no long-run relationship between the GDP and PC series.
All results from the panel integration and co-integration suggest that the panel causality relationship can be examined within a timestationary VAR framework, instead of an error correction VAR framework. Therefore, we apply the first difference operator for the GDP and PC series to get time-stationary VAR models for panel causality. The new series become the growth of real GDP per capita (DGDP) and the change of domestic credit to the private sector (percentage of GDP) (DPC). 
Table 2

Pedroni panel co-integration test

\begin{tabular}{|l|c|}
\hline & GDP - PC \\
\hline Panel statistics & \\
\hline Panel v-stat & 0.4687 \\
Panel rho-stat & 0.3494 \\
Panel pp-stat & -0.5119 \\
Panel adf-stat & -0.6314 \\
\hline Group statistics & \\
\hline Group rho-stat & 1.5652 \\
Group pp-stat & 0.3223 \\
Group adf-stat & -0.2937 \\
\hline Note: Number of countries $(\mathrm{N})=24$ and periods $(\mathrm{T})=31$ & \\
Maximum lag on Schwarz information criterion $(\mathrm{SIC})$ is three. & \\
\hline
\end{tabular}

\subsection{Panel causality results}

Holtz-Eakin et al (1988) suggest that the lag length should be less than one-third of the total time period to avoid the over-identification problem. The Sargan test is a test of the validity of instrumental variables. It is a test of the overidentifying restrictions. The hypothesis being tested with the Sargan test is that the instrumental variables are uncorrelated to some set of residuals, and therefore they are acceptable, healthy, instruments. The ArellanoBond test is a test for the first and second order serial correlation in the first-differenced residuals under the null hypothesis of no serial correlation. Full details on these tests and the estimation procedure may be found in Arellano and Bond (1991). We use two Wald test statistics that follow a chi-squared distribution with $(k-m)$ degrees of freedom. The Wald1 test is a test for the significance of the overall regression model under the null hypothesis that is $\alpha_{j}=\beta_{j}=0$ and $\delta_{j}=y_{j}=0$ for $j=1, \ldots, 9$ equations (11) and (12), respectively. The Wald 2 test is for the null of no causality under the null hypothesis that is $\beta_{j}=0$ and $\delta_{j}=0$ for $j=1, \ldots, 9$ for equations (11) and (12), respectively.

Table 3 presents the results of the panel causality from the GMM estimators. We set the maximum lag length as nine years, that is, less than one-third of the total time period, and test its validity by using the Sargan test. The Sargan test does not reject the validity of this set of instruments in all the equations (except for all BC-DGDP equations from one lag to nine lags). The Arellano-Bond test also accepts the null hypothesis of no serial correlation. All the estimated models are significant at the 1 per cent level. These results show that the models are well specified, and the assumptions for the panel GMM estimator are satisfied at nine lags.

\section{Table 3}

Panel GMM estimation for causality

\begin{tabular}{|l|c|c|c|c|c|c|}
\hline Variables & DGDP-BC & BC-DGDP & DGDP-DPC & DPC-DGDP & DGDP-LL & LL-DGDP \\
\hline Lags & 9 & 9 & 9 & 9 & 9 & 9 \\
\hline Wald1 Test (18) & $\begin{array}{c}196.63 \\
{[0.0000]}\end{array}$ & $\begin{array}{c}9379.13 \\
{[0.0000]}\end{array}$ & $\begin{array}{c}181.15 \\
{[0.0000]}\end{array}$ & $\begin{array}{c}1074.26 \\
{[0.0000]}\end{array}$ & $\begin{array}{c}361.84 \\
{[0.0000]}\end{array}$ & $\begin{array}{c}1610.65 \\
{[0.0000]}\end{array}$ \\
\hline Wald2 Test (9) & $\begin{array}{c}22.18 \\
{[0.0083]}\end{array}$ & $\begin{array}{c}37.29 \\
{[0.0000]}\end{array}$ & $\begin{array}{c}5.37 \\
{[0.8011]}\end{array}$ & $\begin{array}{c}29.31 \\
{[0.0006]}\end{array}$ & $\begin{array}{c}17.73 \\
{[0.0385]}\end{array}$ & $\begin{array}{c}12.89 \\
{[0.1678]}\end{array}$ \\
\hline
\end{tabular}




\begin{tabular}{|l|c|c|c|c|c|c|}
\hline Arellano-Bond Test & $\begin{array}{c}0.18 \\
{[0.8567]}\end{array}$ & $\begin{array}{c}0.47 \\
{[0.6371]}\end{array}$ & $\begin{array}{c}0.43 \\
{[0.6649]}\end{array}$ & $\begin{array}{c}-0.66 \\
{[0.5072]}\end{array}$ & $\begin{array}{c}0.30 \\
{[0.7675]}\end{array}$ & $\begin{array}{c}-0.38 \\
{[0.7011]}\end{array}$ \\
\hline Sargan Test & $\begin{array}{c}366.84 \\
{[0.5219]}\end{array}$ & $\begin{array}{c}346.09 \\
{[0.0000]}\end{array}$ & $\begin{array}{c}360.29 \\
{[0.6174]}\end{array}$ & $\begin{array}{c}390.17 \\
{[0.2150]}\end{array}$ & $\begin{array}{c}359.35 \\
{[0.6307]}\end{array}$ & $\begin{array}{c}385.29 \\
{[0.2691]}\end{array}$ \\
\hline
\end{tabular}

The results for the causality between the financial development indicators and economic growth are as follows: there is a bi-directional causal relationship between the growth of real GDP per capita and the domestic credit provided by the banking sector; there is a one-way causal relationship between domestic credit to the private sector and the growth of real GDP per capita; and the growth of real GDP per capita causes a higher level of financial depth. Higher liquid liabilities lead to higher future per capita GDPs in sub-Saharan African economies.

Our empirical result is in line with earlier studies suggesting that credit ratios capture changes in economic growth better than the financial depth variable does. Many researchers suggest that credit to the private sector represents an accurate indicator of the functioning of financial development. Therefore, most of the financial developments have occurred within the banking systems in African countries (see Ghirmay 2004), any expansion of the domestic credit provided by the banking sector or the domestic credit to the private sector will promote economic growth per capita in sub-Saharan African countries.

Because the financial sectors in sub-Saharan Africa are not well developed, deeper and more efficient financial markets are needed to improve their levels of economic development. Our empirical results suggest that the financial sector affects economic growth mainly through an increase in the efficiency of investment. In order to support faster economic growth, sub-Saharan African countries should expand and improve their credit systems through appropriate regulatory and policy reforms.

\section{6}

\section{Conclusion and policy implications}

This paper investigates the causal links between financial development and economic growth in a sample of 24 sub-Saharan African countries over the period 1975-2005. The paper contributes to the literature by exploring the growth-financial development nexus in the African context and provides some empirical evidence. The empirical methodology is based on the Pedroni Panel Cointegration Test and Panel GMM estimation for causality. The three main findings of the study can be summarised as follows:

i) The results of the panel co-integration analysis provide evidence of no long-run relationship between financial development and economic growth.

ii) The credit ratios capture changes in economic growth better than the financial depth variable in the short-run. Any expansion of the domestic credit provided by the banking sector (BC) or the domestic credit to the private sector will promote economic growth per capita in sub-Saharan African countries. Because of a positive interaction between the domestic credit provided by the banking sector and economic development, countries should liberalise the economy while liberalising the banking sector.

iii) The growth of real GDP per capita also causes financial deepening.

The paper suggests that countries should promote economic growth in order to encourage and thus benefit from financial development. We conclude that sub-Saharan African countries should expand and improve their credit systems through appropriate regulatory and policy reforms in order to support higher economic growth. 


\section{Endnotes}

1 Acknowledgement: The authors are very grateful for the comments of the two anonymous referees, which have significantly improved the depth of analysis of the paper. We also thank the Editor of the journal for his encouragement. The usual disclaimer applies and views are solely those of the authors.

2 For the supply-leading hypothesis, see, for example, Schumpeter (1911), McKinnon (1973), Shaw (1973), Gupta (1984), Fry (1988), Greenwood and Jovanovich (1990), Bencivenga and Smith (1991), King and Levine (1993 a,b), Greenwood and Smith (1997), Khan and Senhadji (2000), Calderon and Liu (2003), and Christopoulos and Tsionas (2004).

3 The four financial development indicators are: (i) the ratio of liquid liabilities to nominal GDP; (ii) the ratio of deposit money bank domestic assets to deposit money bank domestic assets plus central bank domestic assets; (iii) the ratio of credit to the non-financial private sector to total domestic credit (excluding credit to money banks); and (iv) the ratio of credit to the non-financial sector to nominal GDP.

4 For some other studies of the relationship between bank-based or market-based financial systems and growth see Allen and Gale (2000) and DemirgurcKunt and Levine (2001).

5 See Levine $(1998,1999)$ and Barth, Caprio and Levine (2004).

\section{References}

ADJASI, CKD \& BIEKPE, NB (2006) Stock market development and economic growth: The case of selected African countries, African Development Review, 18(1): 144-161.

AGBETSIAFA, DK (2003) The finance growth nexus: Evidence from sub-Saharan Africa, Savings and Development, 28(3): 271-88.

AKINBOADE, OA (1998) Financial development and economic growth in Botswana: A test for Causality, Savings and Development, XX11(3): 331-347. ALLEN, F \& GALE, D (2000) Comparing Financial Systems, Cambridge, MA.: MIT Press.

AL-YOUSIF, YK (2002) Financial development and economic growth: Another look at the evidence from developing countries, Review of Financial Economics, 11: 131-150.

AL-ZUBI, K, AL-RJOUB, S \& ABU-MHAREB, E (2006) Financial development and economic growth:
New empirical evidence from the MENA countries, 1989-2001, Applied Econometrics and International Development, 6: 3-11.

ANDERSEN, TB \& TARP, F (2003) Financial liberalization, financial development and economic growth in LDCs, Journal of International Development, 15: 189-209.

ANDERSON, TW \& HSIAO, C (1981) Estimation of dynamic models with error components, Journal of the American Statistical Association, 76: 589-606. APERGIS, N, FILIPPIDIS, I \& ECONOMIDOU, C (2007) Financial deepening and economic growth linkages: A panel data analysis, Review of World Economics, 143: 179-198.

ARELLANO, M \& BOND, SR (1991) Some tests of specification for panel data: Monte Carlo evidence and an application to employment equations, Review of Economic Studies, 58: 277-297.

ARESTIS, P \& DEMETRIADES, PO (1997)

Financial development and economic growth: Assessing the evidence, Economic Journal, 107: 783799.

ATINDEHOU, RB; GUEYIE, JP \& AMENOUNVE, EK (2005) Financial intermediation and economic growth: Evidence from Western Africa, Applied Financial Economics, 15(11): 777-790.

ATJE, R \& JOVANOVIC, B (1993) Stock market and development, European Economic Review, 37: 623-640. BARTH, JR; CAPRIO, G \& LEVINE, R (2004) Bank regulation and supervision: What works best?, Journal of Financial Intermediation, 13: 205-248.

BECK, T (2002) Financial development and international trade: Is there a link?, Journal of International Economics, 57: 107-131.

BECK, T; LEVINE, R \& LOYAZA, N (2000) Finance and the sources of growth, Journal of Financial Economics, 58: 261-300.

BELL, C \& ROUSSEAU, PL (2001) Postindependence India: A case of finance lend industrialization, Journal of Development Economics, 65: 153-175.

BENCIVENGA, V \& SMITH, B (1991) Financial intermediation and endogenous growth, The Review of Economic Studies, 58: 195-209.

BENHABIB, J \& SPIEGEL, M (2000) The role of financial development in growth and investment, Journal of Economic Growth, 5: 341-360. BERTHELEMY, JC \& VAROUDAKIS, A (1996) Economic growth, convergence clubs, and the role of financial development, Oxford Economic Papers, 48: 300-328.

BLACKBURN, K \& HUNG, VTY (1998) A theory of growth, financial development and trade, Economica, 65: 107-124. 
BOULILA, G \& TRABELSI, M (2002) Financial development and long-run growth: Granger causality in a bivariate VAR structure, evidence from Tunisia: 1962-1997, Working Paper, Faculte des Sciences Economiques et de Gestion de Tunis.

CALDERON, C \& LIU, L (2003) The direction of causality between financial development and economic growth, Journal of Development Economics, 72: 321-334. CASSELLI, F; ESQUIVEL, G \& LEFORT, F (1996) Reopening the convergence debate: A new look at cross-country growth empirics, Journal of Economic Growth, 1: 363-389.

CHOI, I (2001) Unit root tests for panel data, Journal of International Money and Finance, 20: 249-272. CHRISTOPOULOS, DK \& TSIONAS, EG (2004) Financial development and economic growth: Evidence from panel unit root and cointegration tests, Journal of Development Economics, 73: 55-74. CHUAH, HL \& THAI, VC (2004) Financial development and economic growth: Evidence from causality tests for the GCC countries, IMF Working Paper, No.04/XX.

DARRAT, A (1999) Are financial deepening and economic growth causally related? Another look at the evidence, International Economic Journal, 13: 19-35. DE GREGORIO, G \& GUIDOTTI, PE (1995)

Financial development and economic growth, World Development, 23: 433-448.

DEMETRIADES, PO \& HUSSEIN, KA (1996)

Does financial development cause economic growth? Time series evidence from 16 countries, Journal of Development Economics, 51: 387-411. DEMIRGUC-KUNT, A \& LEVINE, R (2001) Financial Structure and Economic Growth: A Cross-Country Comparison of Banks, Markets, and Development, Cambridge, MA.: MIT Press. DEMIRGUC-KUNT, A \& MAKSIMOVIC, V (1998) Law, finance, and firm growth, Journal of Finance, 52: 2107-2137.

ENISAN, AA \& OLUFISAYO, AO (2008) Stock market development and economic growth: Evidence from seven sub-Saharan African countries, Journal of Economics and Business, Forthcoming.

FASE, MMG \& ABMA, RCN (2003) Financial environment and economic growth in selected Asian countries, Journal of Asian Economics, 14, 11-21. FRY, MJ (1988) Money, Interest and Banking in Economic Development, (1 ${ }^{\text {st }}$ ed.) Baltimore, MD: Johns Hopkins University Press.

FRY, MJ (1995) Money, Interest and Banking in Economic Development, ( $2^{\text {nd }}$ ed.) Baltimore, MD: Johns Hopkins University Press. GHIRMAY, T (2004) Financial development and economic growth in Sub-Saharan African countries: Evidence from time series analysis, African Development Review, 16(3): 415-432. GOLDSMITH, RW (1969) Financial Structure and Development, New Haven: Yale University Press. GREENWOOD, J \& JOVANOVIC, B (1990) Financial development, growth, and the distribution of income, Journal of Political Economy, 98: 1076-1107. GREENWOOD, J \& SMITH, B (1997) Financial markets in development and the development of financial markets, Journal of Economic Dynamic and Control, 21: 145-181.

GUPTA, KL (1984) Finance and Economic Growth in Developing Countries, London: Croom Helm. HABIBULLAH, MS (1999) Financial development and economic growth in Asian countries: Testing the financial-led growth hypothesis, Savings and Development, 23: 279-290.

HABIBULLAH, MS \& ENG, Y (2006) Does financial development cause economic growth? A panel data dynamic analysis for the Asian developing countries, Journal of the Asia Pacific Economy, 11: 377-393. HARRISON, P; SUSSMAN, O \& ZEIRA, J (1999) Finance and growth: Theory and new evidence, Federal Reserve Board, Finance and Economics Discussion Paper, No. 1999-35.

HOLTZ-EAKIN, D; NEWEY, W \& ROSEN, HS (1988) Estimating vector autoregressions with panel data, Econometrica, 56: 1371-1395.

HOLTZ-EAKIN, D; NEWEY, W \& ROSEN, HS (1989) The revenues-expenditure nexus: evidence from local government data, International Economic Review, 30: 415-429.

IM, KS; PESARAN, MH \& SHIN, Y (2003) Testing for unit roots in heterogeneous panels, Journal of Econometrics, 115: 53-74.

JUNG, WS (1986) Financial development and economic growth: International evidence, Economic Development and Cultural Change, 34: 336-346. KHAN, SM \& SENHADJI, AS (2000) Financial development and economic growth: An overview, IMF Working Paper, No.00/209.

KING, RG \& LEVINE, R (1993a) Finance and growth: Schumpeter might be right, Quarterly Journal of Economics, 108: 717-738

KING, RG \& LEVINE, R (1993b) Finance, entrepreneurship, and growth: Theory and evidence, Journal of Monetary Economics, 32: 513-542. KLETZER, K \& PARDHAN, P (1987) Credit markets and patterns of international trade, Journal of Development Economics, 27: 57-70.

LA PORTA, R; LOPEZ-DE-SILANES, F, SHELEIFER, A \& VISHNY, R (1997) Legal determinants of external finance, Journal of Finance, 52: 1131-1150. 
LEVINE, R (1991) Stock market growth and tax policy, Journal of Finance, 46: 1445-1465. LEVINE, R (1997) Financial development and economic growth: Views and agenda, Journal of Economic Literature, 35: 688-726.

LEVINE, R (1998) The legal environment, banks, and long-run economic growth, Journal of Money, Credit, and Banking, 30: 596-613.

LEVINE, R (1999) Law, finance and economic growth, Journal of Financial Intermediation, 8: 36-67.

LEVINE, R (2003) More on finance and growth: more finance, more growth, Reserve Bank of St. Louis Review, 85: 31-46.

LEVINE, R, LOAYZA, N \& BECK, T (2000)

Financial intermediation and growth: Causality and causes, Journal of Monetary Economics, 46: 31-77. LEVINE, R \& ZERVOS, S (1996) Stock market development and long-run growth, World Bank Economic Review, 10: 323-339.

LEVINE, R \& ZERVOS, S (1998) Stock markets, banks, and economic growth, American Economic Review, 88: 537-558.

LUCAS, RE (1988) On the mechanics of economic development, Journal of Monetary Economics, 22: 3-42. LUINTEL, KB \& KHAN, M (1999) A quantitative reassessment of the finance-growth nexus: evidence from multivariate VAR, Journal of Development Economics, 60: 381-405.

MCKINNON, R (1973) Money and Capital in Economic Development, Washington, DC: Brookings Institution.

NDIKUMANA, L (2000) Financial determinants of domestic investment in Sub-Saharan Africa: Evidence from panel data, World Development, 28(2): 381-400. NICKELL, S. (1981) Biases in dynamic models with fixed effects, Econometrica, 49: 1417-1426.

ODEDOKUN, MO (1996) Alternative econometric approaches for analyzing the role of the financial sector in economic growth: Time-series evidence from LDCs, Journal of Development Economics, 50(1): 119135.

ODHIAMBO, NM (2005) Financial development and economic growth in Tanzania: A dynamic causality test, African Finance Journal, 7(1): 1-17.

ODHIAMBO, NM (2007) Supply-leading versus demand-following hypothesis: Empirical evidence from three SSA Countries, African Development Review, 19(2): 257-399.

ODHIAMBO, NM (2008) Financial depth, savings and economic growth in Kenya: A Dynamic causal linkage, Economic Modelling, 25(4): 704-13.
OZTURK, I (2008) Financial development and economic growth: Empirical evidence from Turkey, Applied Econometrics and International Development, 8(1): 85-98.

PAGANO, M (1993) Financial markets and growth: An overview, European Economic Review, 37: 613-622. PATRICK, HT (1966) Financial development and economic growth in underdeveloped countries,

Economic Development and Cultural Change, 14: 174189.

PEDRONI, P (1997) Panel cointegration, asymptotic and finite sample properties of pooled time series tests, with an application to the PPP hypothesis: New Results, Economics Working Paper, Indiana University. PEDRONI, P (1999) Critical values for cointegration tests in heterogeneous panels with multiple regressors, Oxford Bulletin of Economics and Statistics, 61: 653-678. PEDRONI, P (2004) Panel cointegration: Asymptotic and finite sample properties of fooled time series tests with an application to the PPP hypothesis, Econometric Theory, 20: 597-625.

PINERO, J; KHAN, H; MELIKYAN, D \&

TAMAZIAN, A (2005) Financial market efficiency, institutions and growth: An international econometric analysis for 1997-2002, Applied Econometrics and International Development, 5: 27-52.

QUAH, D (1993) Empirical cross-section dynamics in economic growth, European Economic Review, 37: 426-434.

QUARTEY, P \& PRAH, P (2008) Financial

development and economic growth in Ghana: Is there a causal link?, African Finance Journal, 10(1): 28-54. ROBINSON, J (1952) 'The Generalization of the General Theory' In: The Rate of Interest and Other Essays, London: MacMillan Publishing Company: 67-142.

SAINT-PAUL, G (1992) Technological choice, financial markets and economic development, European Economic Review, 36: 763-781.

SCHUMPETER, JA (1911) The Theory of Economic Development, Oxford: Oxford University Press. SHAW, ES (1973) Financial Deepening in Economic Development, New York: Oxford University Press. SIMS, CA; STOCK, JH \& WATSON, MW (1990) Inference in linear time series models with some unit roots, Econometrica, 61: 1367-1393.

STERN, N (1989) The economics of development: a survey, Economic Journal, 99: 597-685.

THORNTON, J (1996) Financial deepening and economic growth in developing economies, Applied Economics Letters, 3(4): 243-246. 